\title{
"Is Peking Man Still Our Ancestor?"-Genetics, Anthropology, and the Politics of Racial Nationalism in China
}

\section{YINGHONG CHENG}

In 1993, in response to the international Human Genome Project pioneered by the United States, the Chinese government began to sponsor national projects in conjunction with the international effort. The result of this scientific endeavor confirmed international geneticists" conclusions regarding a very recent "African origin" of all modern humans, or Homo sapiens. This scientific development confronted the longstanding nationalist belief that the "Chinese" had lived in "China" as an independent human group since Homo erectus, represented by the 700,000-year-old Peking Man. By examining the still pervasive political uses of a presumed prehistoric ancestor of the people as well as the controversy sparked by the scientific challenge that has provoked public discussions, this article identifies a potent racial discourse in contemporary Chinese nationalism and connects it to a broader international context.

Keywords: anthropology, Chinese nationalism, genetics, Homo sinensis, the Human Genome Project, Peking Man, racial discourse

T 2001, THE Journal of Asian Studies published an article titled "Peking Man and the to broaden the discussion regarding the prominence of nationalism in post-Mao China by examining a state-sponsored discourse that adapted a body of complex scholarship of archaeology and anthropology of the Stone Age to identify "Chineseness." In that nationalist discourse, Peking Man-a Homo erectus (H. erectus) group that inhabited mountain caves in Zhoukoudian (about 50 kilometers southwest of today's metropolitan Beijing) more than half a million years ago and was first discovered in 1929-was established to represent all Paleolithic hominid groups whose archaeological sites found in China identified them as the direct ancestors of the Chinese people. The most recent estimate is that Peking Man is 770,000 years old (Shen et al. 2009).

At the time of its discovery, Peking Man pushed back the timeline for studies of human evolution by about half a million years from Neanderthals and put China in the field's limelight. But now the key point in understanding the significance of this Chinese version of human evolution involves a debate between the world's mainstream paleoanthropologists and their Chinese peers. While the former adopt the theory first proposed by Rebecca Cann, Mark Stoneking, and Allan Wilson in their famous 1987

Yinghong Cheng (ycheng@desu.edu) is Professor of History at Delaware State University. 
article "Mitochondrial DNA and Human Evolution" and believe that both H. erectus and Homo sapiens (H. sapiens) originated in Africa and that modern humans are the descendants of the H. sapiens that migrated out of Africa in a time as early as 125,000 years and as late as 60,000 years ago and replaced the previous $H$. erectus groups worldwide, the latter claims that the $H$. erectus group that arrived in the land of what is today's China had independently evolved into $H$. sapiens. Ordinary readers may construe the meaning of the debate simply as a question of whether Chinese share a common modern human origin with the rest of the world, and if not, then exactly how "old" are they-one million or two million years?

Sautman $(2001,95)$ presents the discourse as a pronounced case of racial nationalism, which "holds that each of us can trace our identities to a discreet community of biology and culture whose 'essence' has been maintained through time.” By interpreting some archaeological and fossil evidence, the discourse "undergirds a Chinese patriotism that resonates with a folk taxonomy" that is based on a belief in a fundamental division of the world's people (96).

Sigrid Schmalzer's 2008 book, The People’s Peking Man: Popular Science and Human Identity in Twentieth-Century China, is a comprehensive study of the role of Peking Man in the PRC's ideological indoctrination and political socialization against a backdrop of how modern states used scientific education to shape citizenship. ${ }^{1}$ Schmalzer agreed with Sautman that "a nationalist state agenda has worked to privilege scientific theories that root Chinese ethnic identity in the remote past," which emphasized "the longevity of the Chinese as a biological race and the connection of this race to the Chinese land." She also agreed that such a trend had started to accelerate in the 1980s. However, Schmalzer disagreed with Sautman on the extent of the role such an ethnic identity politics had played in the Chinese emphasis on Peking Man. First, she argued, the Chinese discussion was also a scientific (not merely political) debate, since "the jury is still out on many questions about human evolution," and the Chinese scientific community - archaeologists and paleoanthropologists included - is in general open-minded toward the debate regarding the "foreign" or "native" origin of their ancestor. Second, even the political motive, a claim for China’s central role in human origins - “a question more of prestige in international science" - was more prominent than ethnic identity. Third, the construction of "a concept of a biological race" is "simultaneously destabilized by other meanings produced by scientists, laypeople, and the state itself." Finally, -many people regard human fossils like Peking Man's "not simply as early representatives of their nation or race," but "also family, community, regional, professional, and human identities" (Schmalzer 2008, 248-50).

Thus both Sautman and Schmalzer agreed upon a nationalist agenda behind the Chinese discussion regarding Peking Man, but differed in their assessments of how political the discussion was and whether a racial nationalism characterized such an ancestor discourse. James Leibold's recent work represents an assessment in favor of a more "political" and "racial" interpretation. Leibold traces the trajectory of the construction

\footnotetext{
${ }^{1}$ Such a political agenda in the PRC established a human identity free from the influence of religious creation myths and superstitions regarding the origin of mankind, and helped to promote socialist ethics that exalted physical work by using Peking Man to elaborate what Frederick Engels argued in his The Part Played by Labor in the Transition from Ape to Human.
} 
of a historic China in the development of prehistoric archaeology in modern China that has been predicated on a strong belief in Chinese indigeneity. In his synthesis of that discourse, a concept of a distinctive Chinese race has obviously been part of the nationalist context in which prehistoric human fossils and cultural remains are highly valued. By the time of the early PRC, "Peking Man was now clearly positioned as the direct, linear ancestor of Homo sapiens, the yellow race, and the zhonghua minzu (Chinese nation)" (Leibold 2011, 346).

This article expands the discussion of Peking Man's significance for contemporary Chinese nationalism based on important developments either not examined in the previous literature or new since then. First, it emphasizes that since the 1990s, Peking Man's assumed ancestor status for the Chinese people has been further valorized as a symbol in state-sanctioned patriotic mobilization, instead of mainly a paleoanthropological interpretation in nationalist discourse, as Sautman (2001), Schmalzer (2008), and Leibold (2011) have analyzed. Second, this article focuses on the Chinese discussion of genetic challenges to this ancestorship. While previous literature (especially Sautman) explained such a challenge more in scientific terms, this article sets the challenge in a historical context of China's participation in the international Human Genome Project (HGP) in the late 1990s and early 2000s (a fact rarely examined in contemporary China studies) for an understanding of the provocation of the debate as well as actions taken by the Chinese state and scientific community. Third, while acknowledging the archaeological ground for China-origin Chinese (COC), criticized as a politically motivated assumption by Sautman (2001) but allowed as a legitimate scientific hypothesis by Schmalzer (2008), this article nonetheless reveals in detail the academic debate between the two theories regarding the origin of the people. While geneticists in general hold a belief in Africa-origin Chinese (AOC), anthropologists defend the COC theory. The debate has carried an enhanced political sensitivity due to the discourse strategies involved. In other words, the issue is scientific (there is indeed archaeological evidence in favor of the COC theory), but the way it is addressed in many occasions reads political. Fourth, this article shows how both AOC and COC lay supporters fully understand the nationalist implications immersed in such a professional debate and have engaged each other in a public discussion through various media channels. This new phenomenon is analyzed in light of a broader national ideological divide between ultranationalists and liberal-oriented segments. Chinese society's more diverse attitude toward Peking Man, as Schmalzer (2008) emphasized, now includes a potent internationalist antidote to the nationalist stimulant.

This article thus argues that, galvanized by the challenge from genetics, the persistent veneration of Peking Man as the national ancestor and the Chinese discussionsboth academic and popular - of the challenge have revealed more political and especially racial meanings of the subject. The fact that society scientifically accepts the AOC theory cannot obscure the fact that the COC theory still serves a nationalist agenda. To the contrary, the coexistence of the two theories only enhances the tension within Chinese nationalist politics. Inspired by international studies of similar discourses dubbed, for example, Homo europaeus, Homo alpinus, and Homo israelensis, which constructed various imagined "ancestors" that bequeathed essentialized communal traits to their posterity, this article names the Chinese discourse "Homo sinensis," but emphasizes its much more prehistoric and therefore biological root. This article also contextualizes the subject 
in a rising racial nationalism in China since the 1980s that epitomizes "Chineseness" with explicit racial taxonomies in a mystified association with the Chinese land. The "Homo sinensis" discourse advances this nationalism by elevating Chinese civilization among the world's civilizations with a claim for an incontestably greatest antiquity, and informing a most "cohesive force" for nationalist mobilization by establishing a common blood line. Such an ultimate distinction between "us" and "them" endorses the official ideology of "Chinese characteristics," and China's rise is interpreted as the working of a million-year-old exuberant bioenergy, a "vigorous vitality and incomparable creativity" (Wan qiang de sheng ming li he fei fan de chuang zao li 顽强的生命力和非凡的创造力) of a superior civilization.

\section{From the “Sacred Flame” to “Thank You, Our Ancestor!”}

In a culture known for its emphasis on ancestor veneration and family linage, Peking Man's eminence in contemporary China becomes more political, first marked by Zhoukoudian's inclusion on the list of the "National One Hundred Bases for Patriotic Education" by the Department of Propaganda of the CCP Central Committee (DPCCP) in 1997 (Zhongguo gongchandang xinwen 1997), the year of a significant surge of nationalist rhetoric as Hong Kong returned to China after one and a half centuries of British rule. Before, Zhoukoudian was a "National Site for Historical Preservation," established by China’s State Council in 1962. Since the mid-1990s, however, Peking Man has walked out of the museum and history textbooks to assume a role for patriotic mobilization.

Today, Peking Man's physical presence in Chinese nationalism can be glimpsed in the China Centennial Monument (Zhonghua shijitan 中华世纪坛) on West Chang’an Avenue in the center of Beijing. The monument has stood since January 2000 to commence "the China century" and to witness "the great revival of Zhonghua minzu." The monument complex includes a sunken plaza, where an eternal fire called "Altar of the Sacred Flame" burns at its center. The flame was obtained through wood-drilling in the caves of Zhoukoudian on the last day of the century, by actors dressed in caveman costumes, and passed on to Li Ning, a gymnast with numerous medals for China, and then carried to the monument site through a 50-plus-kilometer relay. Hours later, on the eve of the new century, Jiang Zemin, then the leader of the party-state, introduced the flame to the Altar to consummate the state ritual that has established a perennial sign of Peking Man's symbolism (CCTV 2000a).

As a matter of fact, fire taken from Zhoukoudian caves through wood-drilling has induced "sacred flames" to commence public events since the 1990s, involving senior COC anthropologists to indicate the significance of their work for Chinese nationalism. In 1993, the Seventh National Olympics torch was lit there by Jia Lanpo 贾兰坡 (19082001), a legendary anthropologist who discovered three Peking Man skulls in 1936. Named "the flame of civilization," the torch was relayed to Tiananmen Square, where a massive rally was waiting. In July 2005 , to celebrate the commencement of a cultural plaza in Beijing designed for the 2008 Olympics, Liu Dongsheng 刘东生 (1917-2008), also a senior anthropologist, lit the torch with the same method to start a relay carried by cultural and athletic celebrities (see figure 1). Upon its arrival at the plaza, the director of the State Bureau of Cultural Relics and Beijing’s deputy mayor took over the torch to 


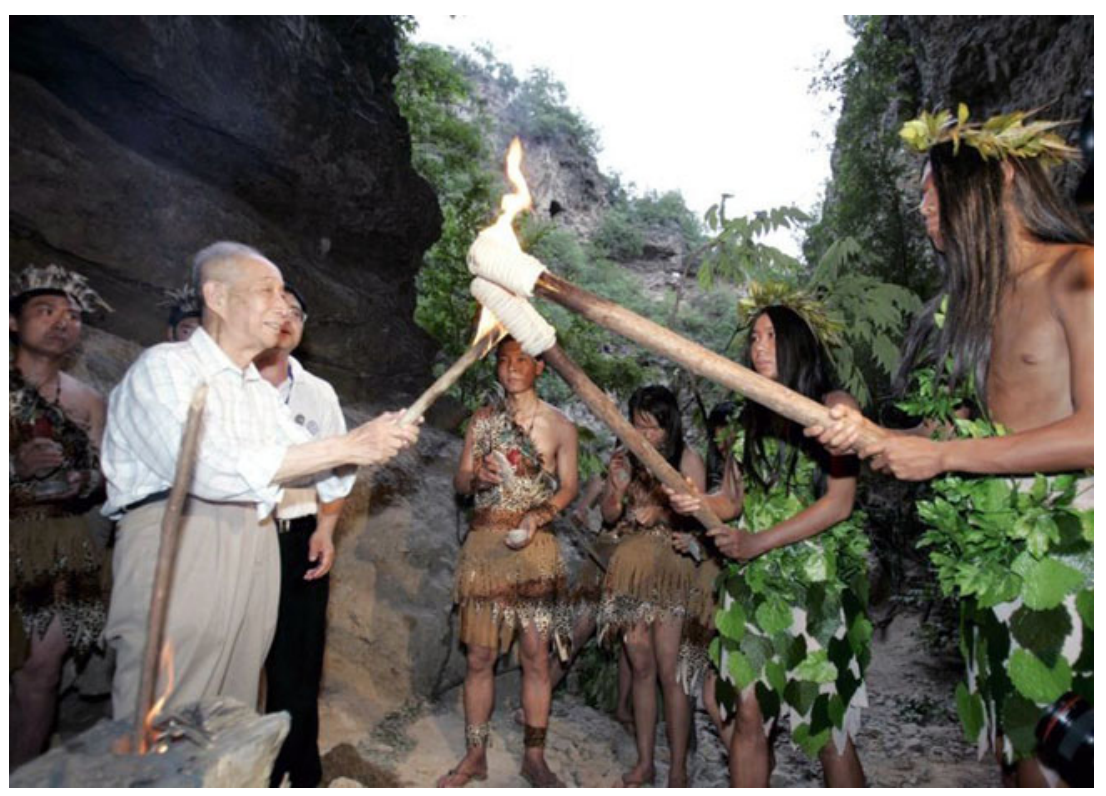

Figure 1. Anthropologist Liu Dongsheng lit the torch with fire created by wood-drilling. The torch was held by young people in caveman costumes who would pass the torch to cultural and athletic celebrities to start a relay from Zhoukoudian to the center of Beijing (Renmin ribao 2008).

ignite "the altar of the sacred flame and restart the fire of human civilization." On August 8,2008 , the site was once again chosen to start the Olympic torch relay's route in the Beijing area (see figure 2).

Since the fossils' discovery, Chinese anthropologists have interpreted ash-like remains in the site as evidence of Peking Man's capability of using fire, which was believed to be the earliest among the world's primitive hominids. The official narrative elaborates its significance: "Making and using fire was the glorious first attempt in the history of mankind to control nature.... The Chinese nation has never given up its unyielding struggle for survival and pursuit for proliferation [and] the fire for hope has never extinguished.... This spirit will inspire China in the new century and the new millennium to ensure the great revival of the Chinese nation" (CCTV 2000b). Historical tourism proclaims, "We can say without any exaggeration that the fire in Zhoukoudian illuminated the world" (Hong Kong Wenweipo 2011). International archaeologists' disagreement with the Chinese interpretation of the evidence is often perceived as a challenge to "China" from "the West," as media reports suggest (Yang 2015).

The fire lit by Peking Man is also treated on the first pages of history textbooks and highlighted in exercises and exams (Qu 2013; Ye 2012), often along with a map of the distribution of primitive people's habitats all over China to show students "a spatial and temporal unity of the Chinese geo-body" (Leibold 2011, 334). Adjectives describing positive traits of Chinese people, such as "diligent," "bright," and "brave," are also used to portray their "ancestor." The ancestry is perceived, as one history teacher so shared with his colleagues, through didactic instruction methods that stretch students' patrilineal imagination into an unmeasurable past. "You ask them: 'How old are you?' 'How old is your father?' 'How old 


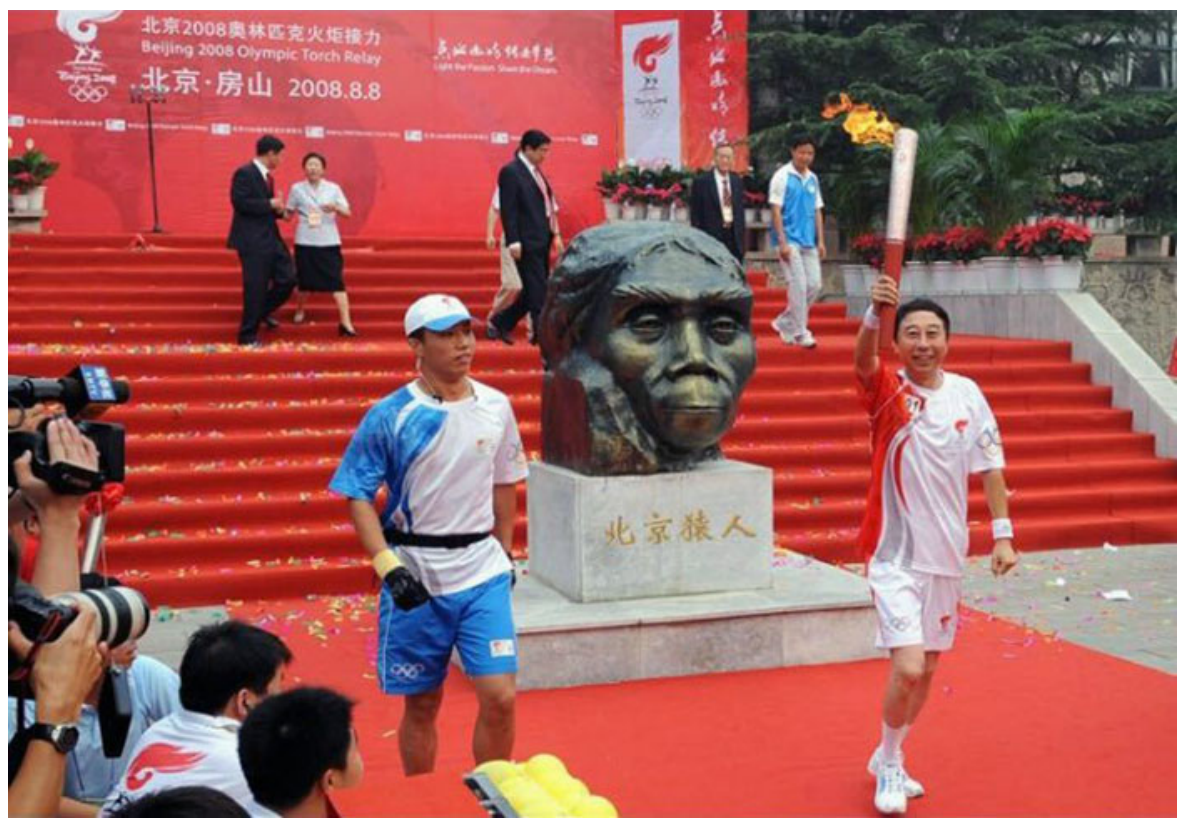

Figure 2. On August 8, 2008, the Olympic torch relay's route in the Beijing area started in Zhoukoudian, where a daylong mass rally was organized with various patriotically themed activities. The bronze head statue projects facial features of Peking Man. Feng Gong, the torch bearer, is a popular actor who was escorted by bodyguards. The same bodyguards also appeared on the torch's global multi-city relay in the same year to fend off various groups of people protesting Beijing's hosting of the Olympics (Zhonghua Renmin Gongheguo Zhongyang Renmin Zhengfu 2008).

is your grandfather?' And so on. As students answer these questions, you help them calculate ' 100 years, 1,000 years, 10,000 years, 400,000 or 500,000 years and one million years', and so on to establish basic concepts of the long history of our fatherland" (Wei 1984, 46).

Popular culture digs deeper into the sundry facts of chronology and relics to attribute the assumed longevity of the Chinese people and civilization to virtues of the ancestor, reflected in a drama titled Primitive Love of Peking Man. A "music, dance, and epic drama," a genre usually reserved for programs of political significance, the play pays tribute to Gen 根 ("root"), the protagonist whose one-character name indicates his ancestral status. A patriarch of a Peking Man group, Gen's valor and shrewdness are key to the survival of the small kin, but his privilege in the rivalry for females causes grievances among young cavemen. As he grows older, he realizes he no longer can produce healthy offspring to carry on the linage, so he allows his young rivals to share his women. In the finale, he throws himself into a bonfire to let others consume his barbequed flesh during a desperate food shortage created by a harsh winter. "Thank you, our ancestor!"- the drama's poster highlights that the virtue of altruism for the survival of the collective has been part of "Chineseness" since the very beginning of the race (see figure 3).

The drama incorporated pop culture and COC. A collaboration between the Zhoukoudian Museum and a group of avant-garde artists (Beijing 1998 Guoji Qingnian Yishu 


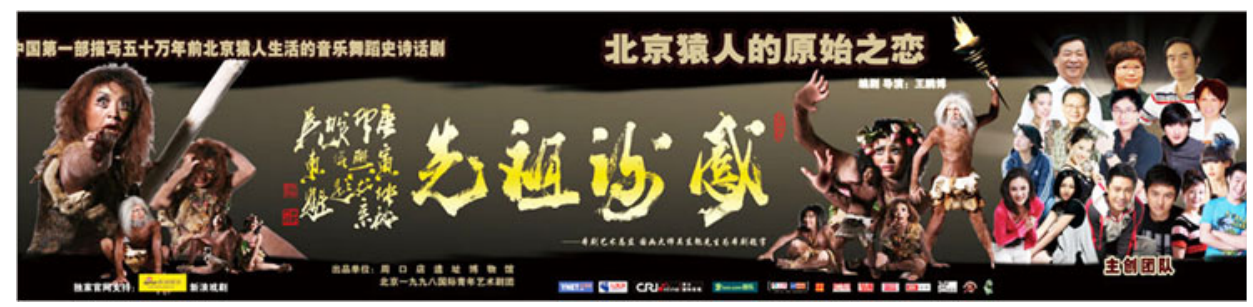

Figure 3. Poster of the drama Primitive Love of Peking Man (the nine big characters on top right). The four big handwritten characters in the center read, from right to left, "Thank you, our ancestor!" (CRJonline 2010).

Jutuan 北京 1998 国际青年艺术剧团, Beijing 1998 International Youth Art Troupe), the drama was created to promote tourism for the museum. To maximize box office proceeds, the drama's poster warned the audience about content inappropriate for young adults and children, by alluding to violent and sexually explicit scenes legitimate in the context of primitive and promiscuous caveman life. However, by the end of the drama, in the flame of sacrifice, all sensual scenarios and expectations are sublimated to a tribute to an ancestral hero's altruism. Fire lit by Peking Man thus not only reflects an overarching theme of Chinese nationalism-concern for the survival of the nation and a call for sacrificial patriotism-but also dramatizes the argument made by anthropologists in their debate with geneticists: fire-making technology likely enabled Peking Man's descendants to survive the Ice Age while their counterparts elsewhere went extinct.

Paradoxically, since the 1960s there have been substantial findings of $H$. erectus fossils significantly predating Peking Man, for example Yuanmou Man (in Chuxiong Yi ethnic autonomous prefecture, Yunnan Province, about 1.7 million years old) and Lantian Man (in Shaanxi Province, about 1.15 million years old). Found in recent years, Jianshi Man (in Enshi Tu and Miao ethnic autonomous prefecture, Hubei Province) is believed to be more than two million years old. But Peking Man and Zhoukoudian still represent the "earliest Chinese" and the "earliest Chinese civilization." Historically and institutionally more established in Chinese archaeological and anthropological experience, Peking Man's name also infers unique values that could foil any challenges from geographically remote and culturally marginal candidates. Scientific facts yield to ideological preferences for an iconic unifying role in nationalist memorial. ${ }^{2}$

\footnotetext{
${ }^{2}$ Unlike in the naming of other famous sites of primitive human habitats, such as Neanderthal and Cro-Magnon, or the ones found in China, which derive from the names of the immediate localities of the discoveries, Davidson Black, a Canadian anatomist and physical anthropologist who supervised and authenticated the discovery in 1929, named the fossils Sina anthropuspekinensis, popularly known as Peking Man, despite the fact that the site is 50 kilometers from metropolitan Peking. The name was literarily translated into Chinese as "Beijing People." Had it been named "Zhoukoudian Man," or even "Longguo Hill Man” (Longguo Hill, meaning "hill of dragon bones," was the name of the immediate site of the Peking Man fossil's discovery), it perhaps would have sounded less magical to Chinese nationalists.
} 


\section{AOC or COC?-A Debate Between Geneticists and Anthropologists}

Peking Man's recent prominence reiterates what Chinese nationalism had assigned to it before. But it has risen in defiance of a cutting-edge scientific challenge in the context of China's participation in the HGP, which enhanced the debate between geneticists and anthropologists with public repercussions. The HGP was launched in 1990 by scientists in the United States and joined by scientists in four other developed nations. By decoding and mapping all genes of the human genome, this post-Cold War global collaboration had an immense impact on the determination and preservation of human genetic distinction and diversity; therefore its results can also be read as "a history book-a narrative of the journey of our species through time" (National Human Genome Research Institute 2012). This "history book" opens with a single African-origin H. sapiens as the ancestor of all modern humans, and goes on to provide genetic interpretations (migration and interbreeding, among other factors) for racial and ethnic distinctions of all peoples in the world.

Despite the obvious scientific benefits the HGP created, sharing national genetic data within the program raised concerns in participating countries. ${ }^{3}$ Weighing the benefits against the risks, the Chinese state decided to join the HGP in 1993 and officially joined in 1998 after five years of preparation, becoming the only developing nation in the project. The National Natural Science Foundation of China (NNSFC), under China's State Council, funded "Research on the Human Genome in China," and established a "southern center" in the State Key Laboratory of Genetic Engineering in the Institute of Genetics, School of Life Sciences, at Fudan University in Shanghai, and a "northern center" in the Human Genome Center at the Chinese Academy of Sciences in Beijing. This national scientific endeavor started with a project titled "Research on Some Structures of Gene Loci in the Genome of Chinese People," which resulted in a contribution to the global genomic map (Jin and Chu 2006, 2). This participation has been viewed as a strategic development in promoting China's national interests_- "The

\footnotetext{
${ }^{3}$ Major political concerns include how to treat DNA data as a new form of national property and security. Paul Rabinow (1999) illustrates a dramatic case in this regard with the French government prohibiting French scientists from offering "French DNA" to Millennium, an HGP-related US biochemical company, in 1994. In China, concerns and debates emerged over possible gene outflow to the West and even alleged gene weapons particularly devised to sap the Chinese nation. Titles of national media reports carried the weight- "To protect our national security, safeguard our genetic code" (China chan jing xinwenbao 2002) and "Is the Chinese nation's gene safe? Are our DNA samples flowing out?" (Renmin ribao 2005). Chinese geneticists explained that what they shared with foreigners were not saliva or blood samples but just certain categories of selected data drawn from these samples. However, this concern still persists and is dramatized in pop culture. A recent movie titled Zhan lang 战狼 (War wolf) tells the story of an ex-American Navy Seal employed by international genetic weapon developers to sneak into China to smuggle out gene samples illegally collected by a US-based unpatriotic Chinese geneticist. The movie can be seen as a political interpretation of discussions about the collection of gene samples in China in the late 1990s and early 2000s by Dr. Xiping Xu, a Harvard-based Chinese American biologist, for research on chronic diseases. Xu's projects were funded by the US National Institutes of Health and were also associated with Millennium. Chinese scientists and media later became alarmed about Xu's research for ethical and legal reasons, which prompted a US government investigation (Harvard School of Public Health 2003).
} 
battle for genetic resources is as important as a battle for territory," as the title of an interview with the director of HGP's Beijing project clearly indicated (Ji 2007).

What led these Chinese participants to call Peking Man's ancestorship into question was research activities conducted by a group of Chinese scholars affiliated in various ways with American institutions. Key to this affiliation was Tan Jiazhen 谈家桢 (1909-2008), a founding figure of Chinese genetics who studied at Caltech in the 1930s with Thomas Hunt Morgan, the father of modern genetics. In the 1950s, after returning to China, Tan resisted Soviet criticism of genetics—especially Morgan's theory-as Western bourgeois science and strove for the survival of the science in China. ${ }^{4} \mathrm{He}$ urged the Chinese state to join the HGP in the 1990s by using his network of Chinese leaders, ${ }^{5}$ succeeded in getting Fudan — his home institution—designated as the "southern center" for China's genomic research, and helped connect China's young geneticists to the international scientific community. Among those scholars, the most important figures include $\mathrm{Jin} \mathrm{Li}$ 金力, a geneticist trained in the United States and a research scientist at the Human Genetics Center, University of Texas-Houston (HGUT) in the late 1990s; Chu Jiayou 褚嘉佑, from the Institute of Medical Biology, Chinese Academy of Medical Science, who was also a visiting scholar in the United States in the 1990s; and Su Bin 宿兵, a post-doctorate fellow at HGUT in the late 1990s. Their international connections made them more aware of the relationship between the "out-of-Africa" theory and the HGP, and they also knew that the data supporting that theory had not covered China. ${ }^{6}$ Intrigued by the contradictions between this international mainstream science and their nationalist beliefs, they viewed the Chinese participation as a test to both.

The data these Chinese geneticists collected in China completely supported the "out-of-Africa" theory. Starting in 1998, they began to publish in international scientific periodicals such as Proceedings of the National Academy of Sciences (PNAS), The American Journal of Human Genetics, Human Genetics, and Science. The first report, "Genetic Relationship of Populations in China," analyzed twenty-eight population groups' (mostly non-Han minorities) microsatellites (a type of molecular marker used to determine kinship or genetic relations) data in China. It concluded that "genetic evidence does not support an independent origin of Homo sapiens in China" (Chu et al. 1998, 11763). A more important report was published in Science in May 2001. Titled "African Origin of Modern Humans in East Asia: A Tale of 12,000 Y Chromosomes," the project used chromosomes as a more accurate data indicator and expanded a sample poll to include Han Chinese (4,592 and 5,127 samples from northern and southern Han Chinese, respectively) and other ethnic groups in East Asia. By identifying a genome mutation carried only by males "which originated in Africa about 35,000 to 89,000

\footnotetext{
${ }^{4}$ The Soviet criticism of genetics was based on Lysenkoism, an officially endorsed pseudo-scientific theory under Stalin that only recognized acquired characteristics but rejected inherited ones in biological evolution.

${ }^{5}$ As an internationally known scientist, Tan was selected in the 1990s by the CCP leadership to be honorary Chairman of the China Democratic League, the largest among eight "democratic parties" that function as the CCP's consultative partners, especially among intellectuals. Tan used his influence to secure China's partnership with the HGP by directly addressing its strategic importance to Jiang Zemin (Zhang 2013).

${ }^{6}$ In 1995, Japanese geneticists provided mitochondrial DNA evidence collected from Japanese to support the "out-of-Africa" theory (Horai et al. 1995).
} 
years ago" but found in all individual samples, the report rejected even a minimal likelihood of modern humans' native origin from East Asia (Ke et al. 2001, 1151).

The first report was originally submitted to Science, but the editor decided to wait, due to concerns over the significance of the subject. Tan Jiazhen then suggested that the authors try PNAS (Huang 2008). It was quickly published by the journal, and Nature immediately followed up with a lengthy commentary. That was the first time the international scientific community confirmed the "out-of-Africa" theory with data collected in the world's most populous country. When "African Origin of Modern Humans in East Asia: A Tale of 12,000 Y Chromosomes" was submitted to Science three years later, it was quickly accepted. Although this research was conducted mainly by Chinese scientists organized in or benefiting from NNSFC projects, their results were first announced in international journals and then disseminated back to China through the media. Such phenomena are often called "import via export" in China, meaning that international recognition helps domestic status. After the 1998 PNAS report made Chinese scientists aware of its challenge to Peking Man's ancestorship, the 2001 Science report got more publicity in China. The NNSFC official bulletin commented that although fossil and anatomical evidence found in China still suggested a possibility of COC, "we very likely have to accept such a point of view: our ancestors came from Africa” (NNSFCB 2002).

A speedy translation and publication of The Journey of Man: A Genetic Odyssey in 2004, only two years after its English edition appeared, aptly joined the challenge in a more popular form. Written by Spencer Wells, the book and a documentary under the same title have been recognized as one of the most influential popular interpretations of the "out-of-Africa" hypothesis. The book has very little on China-since discussions on China had just emerged-but timely quotes Jin's work as "bad news" for those who believe in "multiregional continuous evolution." The Chinese publisher's inclusion of photos and maps on almost every page indicates a strong expectation for a broader audience, and its preface stated that "for Chinese readers, there must be a lot to ponder," because, contrary to the theory that "Chinese people evolved from a uninterrupted development of local 'Peking Man' and other H. erectus groups, the author finds that there is no evidence for such a hypothesis" (Wells 2004, 29).

With further data collection and analysis consistent with these publications in China-the most recent was announced in 2014 by the Institute of Zoology of Kunming in Yunnan Province (IZKYP), which included 6,000 individual samples (IZKYP 2014)_AOC has enjoyed wide appeal in Chinese society, especially in the natural science community. Branches of social sciences and humanities have also felt the impact, with nationalist and ethnic nationalist implications. One such field is linguistics. Quentin Atkinson's hypothesis that phoneme roots of many native languages can be traced back to Africa - an evolutionary linguistic school inspired by "out-of-Africa" theory-is echoed among Chinese linguists in their search for the origin of the Chinese language (Yao 2010). Ethnography has become more prominent in ethnic studies as molecular anthropology is becoming more popular, diverting attention from textual and material-culture analysis to lab results of population genetic surveys and leading to the reinterpretation of the origin and migration of many ethnic minority peoples and their relations with the Han and the Han-dominated state (Jin and Chu 2006, 227-40). One intriguing result is the discussion of the "demic-diffusion model" of Han expansion in southern China-as opposed to the traditional "cultural diffusion model," that is, that Han expansion resulted from non-Han 
peoples' adoption of more civilized Han culture-which shows a predominant pattern of DNA mixing of Han males and non-Han females in southern China's Han population. This result was also first published by Nature (Wen et al. 2004). By interpretation, this could suggest a tantalizing concept of a longue durée, internal, gender-based colonization.

Molecular anthropology has also added new fuel to the fire of the conflict between the mainland and the Taiwanese nationalisms within a particular context: the outbreak of SARS in 2002-3. Taiwanese hematologists' attempts to analyze the impact of the virus among different population groups in East and Southeast Asia made them aware that both the mtDNA and Y chromosomes of aboriginal Taiwanese are much closer to those of Austronesians than those of the mainland Chinese. "We have different blood," claimed a leading Taiwanese hematologist, and the title of her book thus argues for a much more diverse origin of the Taiwanese and refutes China's "same blood, same ancestor" discourse in its nationalist claim over Taiwan ( Lim 2010).

The geneticists' challenge to COC, however, was met with swift resistance from anthropologists in the Institute of Vertebrate Paleontology and Paleoanthropology (IVPP) at the Chinese Academy of Sciences, the institutional spokesperson for COC. The IVPP was formerly the Research Department on the Cainozoic Era (RDCE) in the Institute of the Geological Survey of China in the Chinese Ministry of Agriculture and Commerce, established in 1929, the year of the discovery of the Peking Man fossils. The institute's history was essentially a result of Sino-Euro American scientific collaboration, ${ }^{7}$ which not only trained the first generation of Chinese anthropologists and archaeologists, but also laid the foundation for the COC theory. Franz Weidenreich (1873-1948), an anthropologist at the University of Chicago known for his multiregional hypothesis of human evolution, was honorary director of the RDCE in the mid-1930s, and that experience played a role in the formation of his theory. Most COC advocates - such as Pei Wenzhong 裴文中 (1904-82), the discoverer of the first Peking Man skull in 1929; Jia Lanpo; and Yang Zhongjian 杨钟健 (1897-1979), coordinator of Zhoukoudian's excavation in the 1930s - were trained on site by Western anthropologists and then became elders in the IVPP. They were even all buried in Zhoukoudian at their request. Official historical narratives elevate their professional careers as patriotic commitments, as elsewhere anthropologists and archaeologists who helped construct national history become nationalist heroes. Today, among the IVPP’s researchers, Wu Xinzhi 吴新智, Huang Wanbo 黄万波, and Gao Xin 高星 are ardent COC defenders.

Contrary to genetic data supporting AOC, Chinese anthropologists have shown rich evidence for a seemingly evolutionary continuity in the forms of similarities between $H$. erectus and H. sapiens morphological, anatomical, and cultural remains found in China. Morphological and anatomical evidence include such physical features as a flat front face but projecting cheekbones, shovel-shaped incisors, a low nasal bone, and rectangular-shaped eye sockets. Cultural remains evidence shows that quartz sandstone tools fashioned by chopping seem dominant from 1.7 million years ago to about 30,000

${ }^{7}$ The institute was affiliated with Peking Union Medical College (established by the American Board of Commissioners for Foreign Missions), especially its anatomical department, which at the time was the institutional home for physical anthropology. Between 1929 and the outbreak of the Pacific War, Euro American scientists assumed responsibilities for the institute's administration, and the Rockefeller Foundation financed the work on the archaeological site. 
years ago, but in Africa and the Middle East (a corridor for H. erectus and H. sapiens' journeys "out of Africa"), tool-making technology seems more advanced and obsidian hand axes are commonly found. So the COC argument is, if AOC is true, then why didn't those African-originated H. sapiens bring that technology to China (Gao 2010; Hua 2009b; Wu 2006)? More generally, for COC supporters, a nationwide distribution of thousands of archaeological sites of both $H$. erectus and H. sapiens makes any scenario of a complete replacement by a single foreign species hard to believe.

Anthropologists responded to AOC in the first media reports on geneticists' work in the summer of 2000, in which they were interviewed, especially Wu Xinzhi. Wu, the chief opponent of AOC, used fossil data in East Asia to propose a multiregional evolution model for modern humans with the American Milford H. Wolpoff and the Australian Alan G. Thorne (1939-2012) (Wolpoff, Thorne, and Wu 1984). Wu has since maintained that "four main races in the world all linked to a more archaic human species in their respective locations, all native born" (Wu 2008). Wu told the newspaper that fossils were the most direct evidence, while DNA was indirect and fragmentary. ${ }^{8}$ As he stated, "Over the last 50 years, Chinese archaeologists have found many sites of paleoanthropological fossils and more than a thousand locations of Paleolithic culture remains. [They show] there were no disconnections between $H$. erectus, represented by Peking Man, and modern Chinese, and [the evolution was] an 'expansion like a river network with small amount of interbreeding" (Huashengbao 2000). Three months later, in an article titled "Is Peking Man still our ancestor?," Wu reiterated the possibility of an incidental interbreeding between African-originated and China-evolved H. sapiens (Wu 2000). This referred to some H. sapiens anatomical features found in China, such as round-shaped eye sockets and projecting occipital bones, which appeared more common in Europe (Wu 2008). This revisionist reconciliation with genetics has yet to find critical evidence, although geneticists recently have begun to suggest a similar scenario in Neanderthal Man (Green et al. 2010; Pääbo 2014). As opposed to a phylogenetictree concept of both $H$. erectus and $H$. sapiens with Africa as the common root, Wu accepted the former but insists on his "river network [meaning multiple sources of origin] with a small amount of interbreeding" hypothesis for the latter's global evolution. A multiregional evolution with incidental mixing, rather than a single African-origin mutation and replacement, Wu's model for H. sapiens has been COC's theoretical paradigm.

Responding to anthropologists' defensive arguments, the geneticists have mainly stood the ground of their own discipline with undisputable evidence for AOC. They also call attention to the difficulty in determining the relatedness between two human groups simply by matching some facial and skull resemblances, which could be subject to observers' preconceptions. More importantly, they point to a breakage of archaeological evidence in the assumed evolutionary continuation found in China. This breakage is an absence of evidence of fossils and cultural remains for the time between 100,000 and 40,000 years ago, a key stage in which $H$. sapiens (early modern humans) evolved into H. sapiens sapiens (complete modern humans). As Jin Li and others have explained,

${ }^{8}$ According to Schmalzer, who interviewed Wu Xinzhi in 2005, Wu invited Jin Li to the IVPP (time 
this breakage is not an accident but was created by the quaternary glacier, which caused the extinction of many species globally. After that era, a new H. sapiens migrated from Africa and spread all over the world (Jin and Chu 2006, 234-35). In response, anthropologists have argued that the climate in some parts of East Asia during the Ice Age was relatively milder, and because primitive humans there were able to make fire, they might well have been able to survive the cold. Therefore, the fire made in Zhoukoudian caves once again set ancestors of the Chinese apart from their peers elsewhere, a technical plausibility moralized in the drama Primitive Love of Peking Man. Since the debate started, the anthropologists' main task has been to find the missing link in the evidence that will testify to the survival of Peking Man's descendants throughout the Ice Age.

As the debate was made public, the Chinese media's attitude reflected this scientific divide but often sensationalized its nationalist implications. Reports were either titled "Peking Man is not our ancestor anymore!" or "Chinese archaeologists are once again challenging the universal 'African origin' of modern humans!” (Chen 2011). But a more neutral, ambivalent position, or one that was sympathetic toward COC but with “a careful agnosticism” (Schmalzer 2008, 270), was also common. CCTV's involvement showed such a position with palpable nationalistic sentiment. Responding to international popular media presentations on AOC, CCTV came up with a Chinese version of the story, a five-episode program titled Where Did the Chinese Come From? in 2011. The program admitted that AOC was currently the mainstream science but presented COC as a legitimate hypothesis. The episode narrating the debate was titled "The Remote Eden." It claims, half-jokingly, that since international geneticists used mitochondrial DNA (the matrilineal line) to trace human evolution elsewhere, thus known as "Eve theory," but Chinese geneticists used Y chromosomes (the patrilineal line), China should still be proud of being "the remote Eden" where an "Adam" has been identified to consummate the evolutionary union.

\section{An Academic Debate with Political Discretion}

This Chinese debate constitutes part of the international discussion on the impact of DNA studies on many fields of unsettled issues, especially related to history and identity (Wailoo, Nelson, and Lee 2012a). The cleavage between COC and AOC mirrors an international debate between a minority and a majority of anthropologists since Cann, Stoneking, and Wilson's 1987 co-work. The former claims multiregional origins for H. sapiens, as pioneered by Weidenreich and now represented by Milford Wolpoff and Rachel Caspari. These anthropologists are fully aware of the political implications of the discussion, since Cann, Stoneking, and Wilson's finding is seen as a scientifically decisive blow to white racism, and call the subject "a public discipline," referring to non-professionals" enthusiasm about the discussion. They feel that their academic standing is often mistaken by the public for polygenism, an outdated anthropological theory of parallel evolution of human races from the genesis that had lent credence to racism in the past. From their perspective, while they are seen as denying that we are "all brothers under the skin," their rivals appear on a "moral high ground" of a politically correct ideology of a universal humanity and therefore are rewarded by an uncritical public, especially the media, with enormous 
popularity. A scientific hypothesis cashes in on a popular social agenda (Wolpoff and Caspari 1997, 54).

This international anthropological school has been essentially "China bound," with Weidenreich's theoretical foundation work some eighty years ago and a collaboration that developed between Western anthropologists and their Chinese colleagues. After a long break under Mao, the relationship quickly resumed with Wolpoff and Thorne's trips to the IVPP in the early 1980s and their meeting with Wu Xinzhi there. They took findings of remarkably substantial evidence for both $H$. erectus and H. sapiens in China in the previous decades as critical evidence for their evolving concept of a multiregional thesis. In 1983, Wolpoff invited Wu to the United States on a National Science Foundation fellowship, based at the University of Michigan, Wolpoff's home institution. These exchanges led to their co-authored 1984 article that reinvigorated the multiregional argument. Since Wilson and Cann's findings in 1987, however, their collaboration has been an alliance against the genetics challenge. The most recent evidence of such collaboration is Wolpoff and Caspari's article published in the IVPP's journal in both English and Chinese (Wolpoff and Caspari 2013).

Instead of "race" in the international discussion, "ancestor" is the key word in the Chinese debate. The political implication in China is about how much "we" are different from the rest of the world, creating a tension between genetic facts and nationalist sentiment. But "ancestor" is functionally a Chinese equivalent of "race." Chinese geneticists and anthropologists are aware of the political implications of their research for Chinese nationalism. But they refrain from an explicit appeal to such an interpretation. Neither a genetically universal modern human origin nor an anthropological "Chinese" pedigree is openly used to occupy a moral high ground or claim political correctness. The discussion is not politicized. But a close reading of the discourse on both sides reveals a delicate discretion in a tension concealed under piles of scientific jargon and research statistics.

In general, the geneticists tend to circumvent political sensitivity, leaving the interpretation of their findings open to their audience. Jin Li, the corresponding author of most articles or research reports written by Chinese geneticists and published in international journals around 2000 and now a leading scientist at Fudan University, has become a spokesperson for AOC through popular science writings, media interviews, and public lectures, and has been recognized as such by his foreign colleagues. Alice Roberts, a British anthropologist who wrote and hosted the BBC's four-episode documentary The Incredible Human Journey, another popular science project in 2009 after The Journey of Man promoting the "out-of-Africa" thesis in which China is well represented, interviewed Jin in his lab. With an "out-of-Africa” standing, Roberts disagreed with Wu Xinzhi in another interview in Beijing for the documentary. Roberts appreciated Wu's kindness in receiving her at the IVPP and showing her skull fossils of Peking Man. With regard to Wu's interpretation of "similar" morphological features between the skull and modern humans, however, Roberts not only remained unconvinced but told Wu that such similarities seemed "subtle" to her. Roberts finds an ally in Jin's lab in Shanghai. Jin's remarks show his awareness of his research's implications for Chinese nationalism, and he seemed delighted about the common origin of Chinese and other modern humans:

Before the project [i.e., the project leading to the 2001 Science report] started, I was hoping that I could identify or could be able to find evidence to support an 
independent origin of Chinese in China, because I am Chinese, I came from China, and through educational process I always believed there was something special about Chinese. [To Roberts's question "How did you feel as a Chinese person?" Jin answered,] After I saw the evidence generated in my laboratory, I think we should all be happy with that, because, after all, modern humans from different parts of the world are not too different from each other and we are all very close relatives. (BBC 2009)

However, when facing domestic media, Jin sounds more neutral. When interviewed by CCTV's program Where Did the Chinese Come From?, Jin only emphasizes his initial doubt about the validity of the "out-of-Africa" theory for the origin of Chinese and his hope for a kind of "different result" with data to be collected in China (CCTV 2011). ${ }^{9}$ In his other public talks, he rarely makes any reference to a Chinese identity to which Peking Man is attributed, despite his staunch position on the validity of his team's findings for the question "from where did we come?" (Jin 2005). He never asks the public and the state to reconsider the popular veneration of Peking Man and has stayed away from words such as "nationalism," "patriotism," or even "history education."

A history teacher's reservation about COC may give us a sense of the self-censoring. In a 2012 interview titled "History education should serve patriotic education but should do so in line with facts," a rare bold title by the author, Li Xiaofeng, a model history teacher in Beijing, begins with the case of Peking Man. Li says he encourages students to think independently, rather than blindly believe the textbook: "If you ask them 'Is Peking Man our ancestor?' they will be confused [since the textbook says yes] - how is it possible that someone tells them Peking Man is not our ancestor?” Li then introduces the controversy between AOC and COC. But he avoids any elaboration on history education and patriotism ( $\mathrm{Li} 2012)$.

With regard to anthropologists, Sautman $(2001,103)$ argues that their work "implies that hominids living in what is now China were 'Chinese' and urges that science should reinforce nationalism by showing an ancient Chinese pedigree.” Acknowledging a nationalist agenda behind Chinese anthropologists' argument, Schmalzer (2008, 270) nonetheless maintains that such an argument is to "defend their discipline's primary data set [i.e., fossils]," and she also believes that "Western ignorance about Chinese fossils" contributes to the nationalist taint of the argument. While both are true, the discourse of anthropologists in recent years does read more suggestive of a lithic-age Chinese identity, which is more assertive than defensive. Without directly referring to nationalism or patriotism, it tends to manifest and transmit itself through a narrative of a set of distinctive attributes claimed to have been found in the entire geological epoch telescoping both the H. erectus and H. sapiens eras. According to anthropologist Gao Xing in a 2010 IVPP annual research review:

[A]ncient humans in China as well as East Asia had maintained continuity and stability in behaviour and technology throughout the entire Paleolithic and early Neolithic ages, developed a pattern of unique and gradual evolution

${ }^{9}$ In an interview, Chu Jiayou also admitted his hope that he would find a "non-African, independent Chinese gene" before he started his research that resulted in the 1998 PNAS report (Huang 2008). 
with a characteristic of inheritance over innovation, and there had not been replacement and interruption. About 800,000 years ago, in southern and central China there appeared hand axes and other items similar to the contemporary Western 'Acheulian-technology' type, and about 30,000 years ago in northern China there appeared 'stone blade technology' with characteristics of later European Paleolithic culture, but they existed very isolated and transiently, like short-lived blossoms, and failed to leave any significant influence on native mainstream culture. Based on such evidence, scholars have suggested that the main group of ancient humans during the Pleistocene era in China and even in East Asia had continued to thrive, never experiencing any disruption, that its culture had powerful vigour for life and presented a successive evolutionary relationship; there were a small number of incidental foreign groups who had brought with them 'non-native' culture, but would soon disappear without any trace in the mainstream culture’s dominance. (Gao 2010)

Gao named this Chinese or East Asian evolutionary pattern a "comprehensive behaviour model" that "was adaptive to local conditions and harmonious and friendly with the native environment, kept the use of environmental resources to a low level by constant migration and relocation, while reforming and assimilating foreign cultures that had occasionally penetrated [local culture]" (Gao 2010).

If Wu's "river-like network" hypothesis for H. sapiens' global evolution answers the question of why an independent origin of Chinese is possible, then Gao's "comprehensive behaviour model" asserts that such an origin is historically inevitable. Superior traits had sustained an archaic hominid group from $H$. erectus to $H$. sapiens over a two million-year geologic time period, showing extraordinary talents and skills in making itself sovereign of the environment while indigenizing foreign influence. But exactly from where did this "powerful vigour" and those fine traits originate? Were they acquired through adaptation to the natural settings, a process in which contingent responses eventually led to structural reconfiguration and intuitive formation, or was it something more inborn? In the context of a strong nationalist tradition that tends to historicize "national characteristics," such an evolutionary adaptability and success narrated in a triumphal tone naturally leads to a perception of an immutable and trans-historical "Chineseness" that arouses awe among its posterity.

This argument for indigeneity and continuity of the lithic-age experience underlines an already clearly drawn trajectory of the development of prehistoric archaeology and ushers in the discourse of Chinese civilization (Leibold 2011, 343-48). It facilitates an authoritative Chinese archaeological claim in the new millennium for an essentially endogenous, self-perpetuating civilization, a phenomenon among world's civilizations. In that claim, China is taken for granted as a prehistorical "given," and there seems to be no need for restrictive clauses such as "in what is today's China," as the spatial relationship between the past and the present is often so clarified by international scholars when necessary. In 2005, The Formation of Chinese Civilization-An Archaeological Perspective, a state-sponsored work by prominent Chinese and Chinese-American archaeologists, was published in both Chinese and English (Chang and $\mathrm{Xu}$ 2005). In this landmark effort to synthesize updated research to reinterpret the origin and formative stage of China, the editors proclaim that their mission is to explore "the particular 
characteristics of the Chinese Paleolithic" (Xu 2005, 7). Five years after genetics rocked the COC, however, the book makes no mention of the debate at all in its first chapter, entitled "Early Humans in China." Xu Pingfang, the author of the Introduction Part II and former director of the Institute of Archaeology, Chinese Academy of Social Sciences, extends the lineage of Chinese history deep into the mid-Pleistocene era- "This 'pre-Qin' period [the period of Chinese history prior to the late third century BCE Qin dynasty], lasting a million or more years, includes the Chinese Paleolithic and Neolithic periods and the Three Dynasties: the Xia, Shang and Zhou" (Xu 2005, 7).

\section{“To Expel Homo SAPIENS, AND to Revive ZhoNGHUA!"}

Ordinary people's responses show that in China the subject is not just a popular science lesson but something unequivocally about who "we" are, a "public discipline" as Wolpoff and Caspari (1997) described. Unlike geneticists and anthropologists, both COC and AOC lay supporters openly politicize the subject. Some find AOC to be a new form of the discredited "Western origin of Chinese civilization," proposed by European scholars in the nineteenth and early twentieth centuries, or a Western ideological conspiracy that uses unpatriotic and fame-hungry Chinese scientists as agents to deconstruct the foundation of Chinese nationalism. For these people, AOC is a "Western" theory while COC is "Chinese," as if the latter was an indigenous Chinese product. Their opponents dismiss such allegations as patriotic paranoia fostered by a hypernationalism that rests on a presumed China/West confrontation.

Similar to multiregionalists outside China, COC defenders feel offended by AOC's media publicity. But their responses are more agitated by nationalism, evident in their distrust of AOC's "Western" origin. Lu Guoyao, a senior philologist, deplores that the "molecular biology-based out-of-Africa theory has prevailed in both 'academic' and 'popular' publications, and even Chinese linguists are now mimicking geneticists.” Lu rejects linguists' discussion as an attempt to relegate the dialectal diversity and complexity of China to a singular nonnative source and to deny the aboriginality of Chinese civilization. He warns his linguistic colleagues that Western scholarship has been frequently discredited for its tendency to pursue novelty and create sensation by making groundless assumptions and far-fetched connections ( $\mathrm{Lu} 2012$ ). In a more sweeping, book-length global historical narrative, The genesis-An evidential study of the Chinese origin of human civilization, an amateur but "erudite" author engages a wide range of academic disciplines to refute AOC as a Western denigration of China accepted by Chinese lacking in cultural confidence. He claims that even H. erectus also originated in China. China is the cradle of all major world civilizations, in his view (Liu Bo 2008).

COC supporters' responses in social media are even more political. Responding to a major report in which both Jin $\mathrm{Li}$ and $\mathrm{Wu}$ Xinzhi were interviewed, one commentator called Jin a "charlatan" and asserted that his "research was either funded by Americans or the money was inveigled from the Chinese government. Such an 'achievement' was surely to be published in a famous [foreign] journal to guarantee him fame and money." Two comments followed: "[They] simply just cannot wait to dissolve our nation's cohesive forces," and "Nowadays many discourses are attempting to marginalize our history; they are bidding for dividing us from all sides, weaken our blood stock, 
confuse us, insidiously make rumors with a purpose to destroy our cultural and racial endurability, undermine our national unifying forces and confidence; it is a pity that our nation has never been short of such scum" (Hua ti 2009a). National History, an avantgarde popular-history journal with a liberal tendency, was labeled "banana" (meaning yellow skin but white core, a racialized aphorism for "unpatriotic Chinese") for a lengthy feature report on the subject. The comment asserted that the journal had an agenda of promoting "national nihilism and Western universalist values" (Hua ti 2009b).

The most radical defense of COC can be found in a cartoon posted on a BBS site with the line "It's time to post this" (Hupu 2009; see figure 4). The Chinese characters on the left side read, from top to bottom: "The great $H$. erectus two million years [ago]; Son of Heaven defends the entrance of his cave; The king would die in the jungles [rather than surrender to a more civilized life?]; No territorial concessions and no war reparations; No he qin [marriage for peace-making] and no na gong [paying tribute]." A probable encounter between H. erectus "Chinese" and H. sapiens "foreigners" is portrayed as a Stone Age skirmish between "foreign" invaders and "national" defenders. On the right side, the two characters in red underneath the two Peking Men render "orthodoxy" and the two in black underneath a more "civilized"-looking man crossed out in red reads "barbarians" (although they are dressed in traditional Chinese gowns). The bottom line (eight large Chinese characters in red) can be translated as "Expel H. sapiens and revive Zhonghua [China]," a modified version of a famous Han nationalist anti-Manchu catchphrase ("Expel the northern barbarians and revive Zhonghua") in the late Qing (Manchu) dynasty. As bizarre as it may seem, the cartoon interprets with an intense feeling the debate between AOC and COC as a trans-historical defense of the Chinese against the foreign at all costs, even a more civilized way of life, a reminder of Chinese anthropologists' argument that had Chinese H. sapiens been foreign in origin, archaeologists would have been able to find more developed tools.

On the other side of the debate, AOC supporters are comfortable with the fact that the Chinese have no prior China-based ancestry, nor an indissoluble relation with the land. National History reports, "Ever since 1929, we have believed that we have been here for hundreds of thousands of years; we have been born here, grown up here and buried here generation after generation. But scientists have recently told us: we actually came from afar" (Huang 2008). The ideological implication of a fake ancestor and a

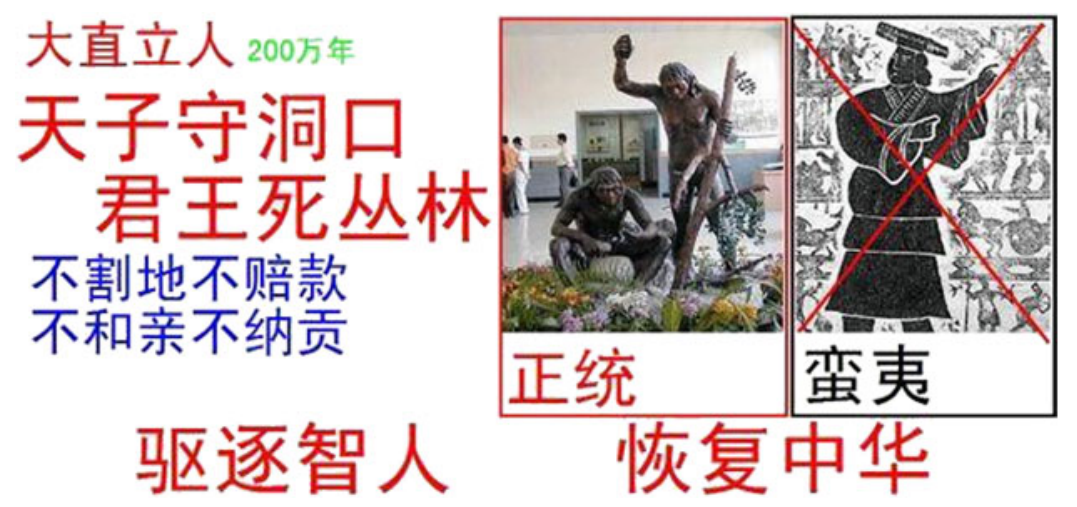

Figure 4. "It's time to post this" (Hupu 2009). 
forged link to the land is obvious for many AOC supporters: in a very devious way, it helps to justify the "Chinese characteristics" in defiance of "universal values," as debated between Chinese liberals and conservatives in the 2000s, because it shows that "we" have been here and unique ever since. But some of them have even gone further. One Internet comment titled "From where did the modern Chinese come? - it is a political question" mentions a Chinese archaeologist's claim, made in his speech at SOAS, London, that the sole purpose of his work in Xinjiang is to prove that the region has been part of China since antiquity:

Paradoxically, those patriotic scholars are just the same as those Western racists who they hate. Racists believe that the noble whites evolved separately from other races; scholars of this land of miracles [shenqi de tudi 神奇的土地, a sarcastic take on patriotic praise of China's presumed greatness] insist that modern Chinese evolved along a single line of ancestry linking Yuanmou Man to Lantian Man and Peking Man to justify their pride in being Chinese. (Din 2010)

AOC supporters' comments on COC believers are hence contemptuous- "hoodwinked" and "mentally retarded." In 2014, a popular essayist responded to COC believers' anger about microblogging provoked by IZKYP's project in 2014 supporting AOC. The author said, "Our history textbooks not only lie in modern history, but in ancient history as well." Our "ancestors" had been "wiped out by Africans!"- what a terrible fact that has made those "nationalists" so "wretched"! The essay ends sarcastically-the CCTV now might well "sing a patriotic song_-oh, Africa, my dear motherland!” (Wang 2014).

\section{A “НоMo SINENSIS"?}

In sum, since China participated in the HGP, implications of the debate surrounding Peking Man's ancestorship for nationalism wrapped in scientific jargon have been well comprehended by various segments of the society, with ultranationalists and a liberal public opinion as two extremes contesting each other. This divergence also cuts through the Chinese party-state-while its scientific authorities acknowledge AOC as mainstream science, its propaganda and education agencies continue propagating COC for patriotic education and nationalist mobilization. To promote Peking Man's archaeological site as a base for national "patriotic education" and commemorate those Chinese anthropologists as patriotic heroes purposely ignores the internationalist spirit of those foreign scientists who committed themselves to Chinese archaeology and anthropology, as well as China's international prominence in these fields. Davidson Black, a leading anthropologist and the chief administrator of the Zhoukoudian site in the early 1930s, from whom Peking Man took its name, was so devoted to the job that he ignored the heart condition he was born with and died on the site while working on the fossils (Jia and Huang 1990, 1). Despite the profound gratitude Chinese anthropologists hold for these foreigners, the official narrative of Peking Man, whenever unavoidable, refers to these foreigners' contributions as "scientific," rarely "internationalist." The word is dodged for its mitigating effect on the patriotic sentiment aroused by Peking Man. 
Ordinary readers who attempt to make sense of the debate may understand it first as a disciplinary one, perhaps reflecting a dichotomy between diachronic and synchronic approaches followed by anthropologists and geneticists, respectively. Secondly, evidence confirming the survival of $H$. erectus descendants throughout the Ice Age has yet to be found. There is also no substantial evidence yet to prove a mix between African-origin H. sapiens and local H. erectus or H. sapiens in East Asia. It could exist. Thirdly, and most important, even if those two types of data-or any type of fossil evidence critically challenging the DNA-based AOC-should be found, ${ }^{10}$ these ancients cannot be called "Chinese" (or "ancestor" of any particular ethnic or national group). Their habitat was not "China" (or the "fatherland/motherland" of any nation-state). The vestige of their activity was not "Chinese civilization." There exists a fundamental difference between a scientific hypothesis of multi-regionalism and its nationalist or racialized interpretation, as Sautman noticed in the works of Wolpoff and Caspari, the leading exponents of the hypothesis, which denied that "anything like the 'races' of today existed before the first modern H. sapiens." However, multi-regionalist scholars in China had not issued "similar disclaimers" (Sautman 2001, 101). Wolpoff and Caspari have since maintained this position, as they stated in their article recently published in China-“All human populations today are equally modern.... It was not our origins that made us what we are, and it is not our genealogy that makes us unique" (Wolpoff and Caspari 2013, 394).

The question of whether and how scientific facts about the human body-living or fossilized, in the form of physical appearance or coded in our DNA — can be used in constructing human social identity as well as narrating historical transformation of such identity is not unique to China. Also, a specific science may be used to either challenge or defend an existing perception about such an identity. As Keith Wailoo and others argue, "science does not exist apart from its contexts and uses," and it could be both liberating and confining in its effect on the popular imagination (Wailoo, Nelson, and Lee 2012b, 4). Genetics in China challenged the Stalinist interpretation of biological evolution in the form of Lysenkoism in the past, and now it undermines racial nationalism. But elsewhere, it has a recorded history of being exploited by state-sponsored racisms in the twentieth century, and as Wailoo and others have shown, the science is still being manipulated for political agendas of nation-states and ethnic groups.

Nadia Abu El-Haj's critical studies of the Israeli discourse on Jewishness are particularly illuminating in this regard. It has been a fundamental assumption of some Israeli historical narratives that contemporary Jews are direct and pure descendants of an original Hebrew people from ancient Palestine. Genetics in the twentieth century and genome studies in recent decades have been used by this discourse as scientific evidence attesting to that history. Nevertheless, technical difficulties and uncertainties unsolved by the discourse aside, especially regarding how to determine who is and who is not a Jew under different historical circumstances, Abu El-Haj (2012) argues that the reading of DNA cannot be directly converted into an identity construct. The barrier between historically formed human consciousness and human bodily facts is epistemological. Abu

\footnotetext{
${ }^{10}$ The most recent fossil evidence (forty-seven teeth) suggesting that $H$. sapiens existed in what is today's China (Daoxian, Hunan Province) between 120,000 and 80,000 years ago was announced in October 2015, although the relationship between the fossils and Peking Man-age H. erectus remains undetermined (Wu Liu et al. 2015).
} 
El-Haj effectively shows how the Israeli discourse has played with genetic data, leaving behind unanswered questions reflecting ambiguity, elusiveness, and ever-shifting emphasis caused by ignoring such a barrier. Her analysis of the problematic use of genetics in Israeli nationalism, therefore, provides comparative perspective as well as a methodological tool in the critique of the use of paleoanthropological science by Chinese nationalism.

The discourse on a pure ancestry; an ancestral home; a natural bond between this ancestor and the environment; and, most of all, a narrative that attributes remarkable lineal continuity to physical, mental, intellectual, and even moral traits unique to this ancestor and its posterity support fanatical racial nationalisms. The efforts to construct racial uniqueness through finding an $\mathrm{H}$. erectus ancestry has led to paleoanthropological hoaxes such as "Piltdown Man" in England over a century ago, and, very recently, the forgery of fossils in Japan by Fujimura Shinichi, a charlatan archaeologist who became a cultural celebrity in the midst of Japan's reemerging nationalism in the 1980s but was debunked in 2000 (Ng 2010; Romey 2001). Although "regarded as illegitimate in our time," as Benjamin Isaac cautions, racism "occurs under different names and in different guises" (Isaac, Ziegler, and Eliav-Feldon 2009, 4). But the political appropriation of COC shows that some classical and prototypical racial thinking persists with little alteration.

Among recent discussions of race and nationalism, Maurice Olender (2009) reveals "a nostalgia for old Aryanistic themes" in Nouvelle École (New School), a French school of classics, in recent decades, which can also provide a comparative perspective. Despite the notoriety of Nazi propaganda of the "Aryan race," the Nouvelle École attributes to the origin of Western European civilization a "perfect Aryan genius" of the "IndoEuropeans" since the Neolithic era, manifesting itself in such traits as "abstraction and metaphysics," "reflection," and particularly "a constant tendency to subordinate the natural by integrating it into the political" (Olender 2009, 47, 68). A moral portrait of such a creature is also implied. These echo the Chinese discourse of ancestral genius, implied in the "comprehensive behavior model," and praise of ancestral valor and virtue. On the national ideological spectrum, many Nouvelle École scholars were leaning toward "various currents of the 'New Right." In China, the most outspoken COC amateur supporters are ultra-nationalists for whom defending a purely indigenous origin is a political cause.

For Olender, the Nouvelle École discourse represented efforts to rehabilitate Homo europaeus (Olender 2009, 55), a discredited racial concept that portrayed a presumed superior human stock with unique social character derived from biological traits. Similar efforts to essentialize and mystify particular human groups can also be found in the discourse about Homo alpinus, a Swiss alpine peasant myth of "a strong, healthy, hardworking, patient, perseverant, good-natured but autonomous human type" (Sommer 2012, 120). Abu El-Haj (2012, 99-108) also dubs the Israeli construct of a pure-blood and single-ancestor Jewishness Homo israelensis. While these discourses involve a relatively recent time in which human civilizations had begun, the Chinese discourse dates back at least a half-million years, sunken deep in pre-human natural history. A "Homo sinensis," a term I invented to refer to the parallel, therefore, is more of a legitimate dub for the assumed prehistorical and trans-historical human stock with more of a biological than a cultural connotation.

The nationalist interpretation of the COC cannot be dismissed as a wild ramification of an already zealous and insular nationalism embraced only by a handful of hardcore, 
out-of-touch conservatives and its influence inflated by social media. It is a neoracial rhetoric rooted in modern China's nationalist tradition. With regard to this tradition, Frank Dikötter (1992) has argued that racial thinking had its own roots in Chinese history but developed into a nationalist discourse in the late nineteenth century with Western racial theories, which identified the Chinese nation with the yellow race, although the category was originally a Western coinage with a racially derogatory connotation (Keevak 2011). Partially based in this Chinese experience, Dikötter (2012) proposed an "interactive model" of the formation of racial thinking in non-Western societies to challenge the diffusion model, which holds that racial thinking was a Western invention and spread out globally. Sautman (1997) has sketched some more recent developments of this racial nationalism in China, epitomized in physical and biological claims such as "descendants of Yan and Huang emperors," "descendants of the Dragon" (a totemic veneration of the dragon as a divine ancestral animal god patronizing China), yellow as the primordial pigment of the skin, the River, the yellow earth, and the imperial legacy, as well as Peking Man as the national ancestor.

Just as the glorification of Peking Man has recently developed into an instrument for patriotic mobilization, the racial nationalism discussed above has become more accessible in society and therefore more popular owing to the invention of new rhetoric and dissemination devices. ${ }^{11}$ For example, "black eyes, black hair, and yellow skin," a set of blatant racial taxonomies, has been employed in popular culture and everyday language with official acquiescence to denote "Chineseness." It has almost become the synonym of "Chinese people," along with the existing "descendants of the Dragon" and "descendants of Yan and Huang emperors." "Chinese heart and Chinese blood," another set of less racial but biologically evocative concepts, has been popularized to essentialize the source of the common belonging for the national unity and a diasporic Chineseness. The most public presentation of these "racial boundary markers" can be found in officially promoted "patriotic songs" created since the 1980s as a major popular culture instrument for nationalist mobilization, with the most acknowledged ones included in the DPCCP list of the "One Hundred Patriotic Songs" (Xinhua she 2009) to celebrate the PRC's sixtieth anniversary. Their titles and lyrics address Chinese identity in passionate as well as melancholy tones, often filled with a sense of the Chinese as a race with an entrenched nationalist grievance. ${ }^{12}$

\footnotetext{
${ }^{11}$ The content of this paragraph is borrowed from Cheng (2015a, 2015b).

${ }^{12}$ For example, "I am proud, I am a Chinese" claims: "Among countless blue and brown eyes, I have a pair of black, diamond-like eyes / I am proud, I am a Chinese / Among countless white skins and black skins, I have yellow, earth-like skin / I am proud, I am a Chinese / My ancestors were the first to walk out of the jungle / my ancestors were the first to start farming." The lyricist was honored as the "people's poet" by the official writers' association and the lyrics have been included in some textbooks of Chinese language and literature. Another song, "The Yellow Race," declares: "Yellow race, walk on earth / Stick out a new chest / After 5,000 years it's finally my turn to step onto the stage / There is no wound that cannot be healed / Ancient might sustains us forever / The yellowness in the soil carries the Orient with doggedness / Everywhere in the world you will see a yellow face / Red blood flows in veins of 1.3 billion people / You say it's my fury / I say it's my attitude / Fearless, marching forward / Are only us, the Chinese / With the yellow heaven above / You will see how I become a true man." (Words in italics are rap.)
} 
Peking Man’s ancestorship advances this racial nationalism. It facilitates the national identity politics in China's rise — a racialized "Chineseness" - as a most cohesive force. Anthony Smith's (2001) concise analysis of archaeology's role in legitimating the ethnic nation is a ready tool for a brief final analysis. All concepts in favor of "the nationalist ideal of the distinctive, territorial nation" backed up by archaeology's presentation of the material culture of the past, such as uniqueness, essentialism, rootedness, authenticity, indigeneity, or more tangibly, soil, lead to a construction of the "historical homeland." The political appropriation of COC has extended the application of these concepts from the ethnic and cultural (measured in thousands of years) to the evolutionary and biological (measured in hundreds of thousands of years). Cultural continuity has been transformed into racial genealogy. A "Chinese identity" finds its ultimate origin not only in an $H$. erectus ancestry but also in an asserted harmony between this hominid and the natural setting. The two fuse into a habitat alien to foreigners from which "motherland/fatherland" (the land is ancestrally "ours") and "Chinese territory since the antiquity" acquire absolute legitimacy. In the final analysis, a racial myth of a million-year-old exuberant bioenergy, called the "vigorous vitality and incomparable creativity," as the current Chinese president reiterated, has become a catchphrase that distinguishes superior "Chinese" from "Others" (Xi 2014).

\section{Acknowledgments}

I am truly grateful to Edward Friedman and Patrick Manning for their generous help and inspiration in my work on the early drafts of this article. I would like to express my deep appreciation to three anonymous readers whose very thoughtful and critical comments helped me to come up with a more comprehensive and balanced analysis. The encouragement and patience of Professor Jeffrey Wasserstrom, the editor of the Journal of Asian Studies, sustained me in the long course of revisions. I thank Yang Bin, Duan Yuhong, and Wang Yuanchong, with whom I had long discussions, and they also helped me in locating and providing some key sources. The research for this article was partly conducted during my fellowship at the Asia Research Institute, National University of Singapore.

\section{List of References}

Aвu El-Haj, Nadia. 2012. The Genealogical Science: The Search for Jewish Origins and the Politics of Epistemology. Chicago: University of Chicago Press.

BBC. 2009. The Incredible Human Journey. Episode 2 (Asia).

Cann, Rebecca L., Mark Stoneking, and Allan C. Wilson. 1987. "Mitochondrial DNA and Human Evolution." Nature 325:31-36.

CCTV (China Central TV) 中国中央电视台. 2000a. “Jiang Ze Min zhuxi dianran Zhonghua shiji shenghuo” 江泽民主席点燃中华世纪圣火 [President Jiang lit the sacred fire for the China Century]. http://www.cctv.com/specials/2000/news/010104.html (accessed July 8, 2015).

. 2000b. “Zhonghua shenghuo: Cong zhoukoudian dao shijitan” 中华圣火 : 从周口店到 世纪坛 [China's sacred flame: From Zhoukoudian to the China Centennial 
Monument]. http://www.cctv.com/specials/2000/news/123007.html (accessed September 8, 2015).

2011. Zhongguoren cong nali lai? Yaoyuan de yidianyuan 中国人从哪里来第三集 遥远 的伊甸园 [Where did the Chinese come from? Episode 3, “The remote Eden."]. http://jishi.cntv.cn/humhis/zhongguorencongnalilai/classpage/video/20091220/ 101037.shtml (accessed June 20, 2017).

Chang Kwang-Chin and Xu Pingfang, eds. 2005. The Formation of Chinese Civilization: An Archaeological Perspective. New Haven, Conn.: Yale University Press.

Chen Daolin 陈道林. 2011. “'Jianshi zhiliren,' tiaozhan renlei zuxian zuizhao qiyuanyu feizhou de xueshuo” “建始直立人', 挑战人类祖先最早起源于非洲的学说 [Homo jianshinsis challenges the theory of African-origin human evolution]. China Daily. http://www.chinadaily.com.cn/dfpd/2011qglianghui/2011-03/06/content_12123321. htm (accessed May 1, 2014).

Cheng, Yinghong. 2015a. “Constructing a Racialized Identity in Post-Mao China.” In China's Transition from Communism: New Perspectives, eds. Guoguang Wu and Helen Lansdowne, 162-87. London: Routledge.

- 2015b. “Gangtai Patriotic Songs and Racialized Chinese Nationalism.” In Race and Racism in Modern East Asia Volume 2: Interactions, Nationalism, Gender and Lineage, eds. Rotem Kowner and Walter Demel, 342-67. London: Brill.

CHINA CHAN JING XINWEN BAO 中国产经新闻报 [China CHAN Jing NEWS]. 2002. "Weile guojia anquan, qing kanguan hao women de yichuan mima” 为了国家安全看管好我们的遗传密码 [To protect our national security, safeguard our genetic code]. http://www.china.com. cn/chinese/TEC-c/131537.htm (accessed September 8, 2015).

Chu, J. Y., et al. 1998. "Genetic Relationship of Populations in China.” Proceedings of the National Academy of Sciences of the United States of America (PNAS) 95(2):11763-68.

CRJONLINE. 国际在线. 2010. “Beijing yuanren de yuanshi zhi lian” 北京猿人的原始之恋 [Primitive love of Peking Man]. http://gb.cri.cn/32464/2010/08/27/ Zt1325s2971266.htm (accessed May 1, 2014).

Dikötter, Frank. 1992. The Discourse of Race in Modern China. London: Hurst \& Company.

2012. "The Racialization of the Globe: Historical Perspectives." In Racism in the Modern World: Historical Perspectives on Cultural Transfer and Adaptation, eds. Manfred Berg and Simon Wendt, 20-40. New York: Berghahn Books.

Din DiN 丁丁. 2010. “Xiandai Zhongguoren cong nali lai’ shi yige zhengzhi wenti” “现代中 国人从哪里来” 是一个政治问题 [“From where did the modern Chinese come?”-it is a political question]. http://book.douban.com/review/3121248/ (accessed May 31, 2014).

GAO XING 高星. 2010. “Zhongguoren qiyuan yanjiu de xin jinzhan” 中国人祖先起源研究的新 进展 [New developments in the research on the origin of Chinese people]. http:// www.ivpp.ac.cn/xwdt/kydt/201004/t20100419_2824934.html (accessed May 3, 2014).

Green, Richard E., et al. 2010. “A Draft Sequence of the Neandertal Genome." Science 328(5979):710-22.

Harvard School of Public Health. 2003. “Conclusion of U.S. Government’s Inquiry into HSPH Genetic Research in China.” Press release. http://archive.sph.harvard. edu/press-releases/archives/2003-releases/press05302003.html (accessed December 20, 2015). 
Hong KONG WENWEIPO 香港文汇报 [HONG KONG WENHUI DAILY]. 2011. "Renlei wenming zihuo dianran” 人类文明之火点然 [Lighting up fire for human civilizations]. http:// paper.wenweipo.com/2011/07/19/zt1107190019.htm (accessed September 8, 2015).

Horai, Satoshi, Kenji Hayasaka, Rumi Kondo, Kazuo Tsugane, and Naoyuki Takahata. 1995. "Recent African Origin of Modern Humans Revealed by Complete Sequences of Hominoid Mitochondrial DNAs." Proceedings of the National Academy of Sciences of the United States (PNAS) 92(2):532-36.

HUA TI 话题. 2009a. “Zhongguoren cong nali lai? DNA jiemi huaxia zu” 中国人从哪里来 DNA揭秘华夏族 [From where did the Chinese come? DNA unravels the secrets of the Chinese people]. http://comment.news.163.com/news_history_bbs/ 51UKFRGF00011247.html (accessed May 29, 2014).

. 2009b. “Zhongguoren zuxian shi feizhouren, tuzhu zenyang xiaoshi?” 中国人祖先是非 洲人, 土著怎样消失 [If the ancestor of the Chinese is African, then how could have natives in China disappeared?]. http://book.163.com/09/1027/13/5MKQ7 MFF00923K7T_7.html (accessed May 29, 2014).

HuAng Aine 黄艾禾. 2008. “Zhongguoren cong nali lai?” 中国人从哪里来 [From where did the Chinese come?]. Guojia lishi 国家历史, October. http://www.china.com.cn/ culture/txt/2009-02/12/content_17265970.htm (accessed May 31, 2014).

HUASHENGBAO 华声报 [HUASHENG NEWS]. 2000. “Zhongguoren shifou qiyuan yu feizhou yinfa geguo xuezhe jilie zhenglun” 中国人是否源于非洲引发各国学者激烈争论 [Whether Chinese originated in Africa has provoked a hot debate among scientists]. June 15. http://tech.sina.com.cn/ology/2000-06-15/28179.shtml (accessed May 31, 2014).

HUPU 虎朴. 2009. “Shi shihou le” 是时候了 [It's time to post this]. http://bbs.hupu.com/ 5111254.html (accessed April 30, 2014; URL now defunct).

Isaac, Benjamin, Joseph Ziegler, and Miriam Eliav-Feldon. 2009. "Introduction.” In The Origins of Racism in the West, eds. Miriam Eliav-Feldon, Benjamin Isaac, and Joseph Ziegler, 1-14. Cambridge: Cambridge University Press.

IZKYP (The Institute of Zoology of Kunming in Yunnan Province) [Zhongkeyuan KunMing DONGWU YanjIUSUO 中科院昆明动物所]. 2014. “Yuanmou yuanren Beijing yuanren bushi xiandairen de zuxian” 元谋猿人北京猿人不是现代人的祖先 [Yuanmou Man and Peking Man are not ancestors of modern humans]. August 25. http://yn. people.com.cn/news/yunnan/n/2014/0825/c228496-22091885-2.html (accessed May 29, 2015).

Ji TAN 季谭. 2007. “Beijing jiyinzu yanjiushuo shuozhang Yang Huanming: Xiang zhengduo guotu yiyang zhengduo jiyin ziyuan” 北京基因组研究所所长杨焕明: 像争夺 国土一样争夺基因资源 [Yang Huanming, Director of HGP Beijing Institute: “The battle for genetic resources is as important as a battle for territory"]. http://wap.sciencenet.cn/info.aspx?id=193697 (accessed April 12, 2015).

Jia Lanpo and Huang Weiwen. 1990. The Story of Peking Man. Beijing: Foreign Languages Press.

JiN Li. 2005. “Dongya renqun de yuanliu yu yichuan jiegou” 东亚人群的源流与遗传结构 [The genetic structure and origin of peoples in East Asia]. Shiji da jiang tang 世纪 大讲堂 (Century Lectures, a televised public forum for important cultural and scientific discussions led by known scholars). http://wenku.baidu.com/view/ 132830ec102de2bd96058818.htmla (accessed May 29, 2014).

JiN Li 金力 and CHU JiAYOU 储嘉佑, eds. 2006. Zhonghua minzhu yichuan duoyangxing yanjiu 中华民族遗传多样性研究 [Studies of the genetic diversity of the Chinese nation]. Shanghai: Shanghai Science and Technology Publisher. 
Ke, Yuehai, et al. 2001. "African Origin of Modern Humans in East Asia: A Tale of 12,000 Y Chromosomes.” Science 292(5519):1151-53. doi:10.1126/science.1060011.

Keevak, Michael. 2011. Becoming Yellow: A Short History of Racial Thinking. Princeton, N.J.: Princeton University Press.

Leibold, James. 2011. "Filling in the Nation: The Spatial Trajectory of Prehistoric Archaeology in Twentieth-Century China." http:/ttweb.latrobe.edu.au/humanities/ profiles/ss/leibold/History_ch11_0311_Leibold.pdf (accessed September 8, 2015).

Li XiaOfeng 李晓风. 2012. "Lishi jiaoxue ying tixian aiguo zhuyi yao gen shishi xiang lianjie” 历史教学应体现爱国主义教育要跟事实相连接 [History education should serve patriotic education but should do so in line with facts]. Xinhuanet, September 26. http://news.xinhuanet.com/video/2012-09/26/c_123765483.htm (accessed May 30, 2014).

Lim MaLI 林玛利. 2010. Women liu zhe butong de xueye 我们流着不同的血液 [We have different blood]. Taipei: Qianwei Publisher.

LiU Bo 流波. 2008. Yuan-Zhonghua wenmin yuanliu kao 源一人类文明中华源流考 [The genesis-An evidential study of the Chinese origin of human civilization]. Changsha: Hunan Renmin Publisher.

Liv, Wu, et al. 2015. "The Earliest Unequivocally Modern Humans in Southern China." Nature 526:696-99. doi:10.1038/nature15696.

Lu GUOYAo 鲁国尧. 2012. 'Yige yuyan xueren de 'gaunzhan' yu 'yishuo'-Guanyu Zhongguo gurenlei xuejia dui jiyu fenzi shenwu xue de 'chuzi feizhou shuo' de jinan”一个语言学人的“观战”与“臆说”一一关于中国古人类学家对基于分子生物学的“出自非 洲说”的诘难 [A linguist's view on Chinese paleoanthropologists' challenge to the molecular-based “out of Africa” hypothesis]. Gu hanyu yanjiu 古汉语研究 97(4).

National Human Genome Research Institute. 2012. "What Is the Human Genome Project?” https://www.genome.gov/11511417 (accessed December 20, 2015).

NG WaI-Ming 吴伟明. 2010. “Riben kaoguxue yu minzhu zhuyi: Qianqi jiushiqi nie zhao shijian de yishixintai” 日本考古学与民族主义: 前期旧石器捏造事件的意识形态 [Japanese archaeology and nationalism: Ideologies behind the early Paleolithic frauds in Japan]. Si yu yan 思与言 48(4):85-108.

NnSfCB (National Natural Science Foundation of China Briefing) [Zhongguo GUOJIA ZIRAN KEXUE JIJINHUI QINGKUANG JIAOLIU 中国国家自然科学基金会情况交流]. 2002. “Y ranseti yanjiu jieshi: Xiandai Zhongguoren qiyuan yu feizhou” Y染色体研 究揭示:现代东亚人起源于非洲 [Research on Y chromosome has revealed that modern East Asians originated from Africa]. February 6. http://www.nsfc.gov.cn/ nsfc/sysmodels/new_detail.aspx@infoid=3381.htm (accessed December 20, 2015).

Olender, Maurice. 2009. Race and Erudition. Cambridge, Mass.: Harvard University Press.

Pä̈̈во, Svante. 2014. Neanderthal Man: In Search of Lost Genomes. New York: Basic Books.

QU YIXIAN 曲一线. 2013. Chuzhong xitihua zhishi qing dan (lishi) 初中习题化知识清单（历史） [Junior high school history key knowledge (history)]. Beijing: Capital University Publisher.

Rabinow, Paul 1999. French DNA: Trouble in Purgatory. Chicago: University of Chicago Press.

RENMIN RIBAO 人民日报 [PeOPLE'S DAILY]. 2005. “Zhonghua minzu shifou jiyin an quan? Women de jiyin shifou wailiu?” 中华民族是否基因安全? 我们的基因是否外流? [Is the Chinese nation's gene safe? Are our DNA samples flowing out?]. April 19. http:// scitech.people.com.cn/GB/25893/3331825.html (accessed May 30, 2014). 
— 2008. “Renwen aoyun zhanshi Zhonghua meili” 人文奥运展示中华魅力 [A more cultural Olympics shows China's charm]. March 27. http://pic.people.com.cn/GB/ 31655/7051538.html (accessed May 20, 2015).

Romey, Kristin M. 2001. “God's Hands' Did the Devil's Work.” Archaeology 54(1). http://archive.archaeology.org/0101/newsbriefs/godshands.html (accessed September 26, 2015).

Sautman, Barry. 1997. "Myths of Descent: Racial Nationalism and Ethnic Minorities in the People's Republic of China." In The Construction of Racial Identities in China and Japan: Historical and Contemporary Perspectives, ed. Frank Dikötter, 75-91. London: Hurst \& Company.

—. 2001. "Peking Man and the Politics of Paleoanthropological Nationalism in China." Journal of Asian Studies 60(1):95-124.

Schmalzer, Sigrid. 2008. The People's Peking Man: Popular Science and Human Identity in Twentieth-Century China. Chicago: University of Chicago Press.

Shen, Guanjun, Xing Gao, Bin GaO, and Darryl E. Granger. 2009. "Age of Zhoukoudian Homo erectus Determined with ${ }^{26} \mathrm{Al} /{ }^{10} \mathrm{Be}$ Burial Dating." Nature 458: 198-200. doi:10.1038/nature07741.

Smith, Anthony D. 2001. "Authenticity, Antiquity and Archaeology." Nations and Nationalism 7(4):441-49.

Sommer, Marianne. 2012. "Do You Have Celtic, Jewish or Germanic Roots?” In Identity Politics and the New Genetics: Re/Creating Categories of Difference and Belonging, eds. Katharina Schramm, David Skinner, and Richard Rottenburg, 117-40. New York: Berghahn Books.

Wailoo, Keith, Alondra Nelson, and Catherine Lee, eds. 2012a. Genetics and the Unsettled Past: The Collision of DNA, Race, and History. New Brunswick, N.J.: Rutgers University Press.

_ 2012b. "Introduction: Genetic Claims and the Unsettled Past." In Genetics and the Unsettled Past: The Collision of DNA, Race, and History, eds. Keith Wailoo, Alondra Nelson, and Catherine Lee, 1-29. New Brunswick, N.J.: Rutgers University Press.

WANG SiXIANG 王思想. 2014. “Women doushi ruqing zhe de houdai” 我们都是入侵者的后代 [We are all descendants of invaders]. http://t.qq.com/wangxy?mode=0\&id= $407275134205245 \& p i=9 \&$ time $=1409371707$ (accessed May 29, 2014).

WEI FutANG 魏芙塘. 1984. “Zai zhongxiaoxue lishi jiaoyu zhong zhongshi dui xuesheng jin xing aiguo zhuyi jiaoyu” 在小学历史教学中重视对学生进行爱国主义教育 [Engage students in patriotic education in elementary and middle school history classes]. Jiangsu Education 18:45-47.

Wells, SPENCER. 2004. Chu feizhou ji: Renlei zuxian de qianxi shi 出非洲记-人类祖先迁徙史 [Journey out of Africa: The epic of human ancestors' migration]. Beijing: Dongfang chubanshe.

Wen, Bo, et al. 2004. "Genetic Evidence Supports Demic Diffusion of Han Culture." Nature 431:302-5. doi:10.1038/nature02878.

Wolpoff, Milford, and Rachel Caspari. 1997. Race and Human Evolution: A Fatal Attraction. New York: Simon \& Schuster.

—. 2013. "The Origin of Modern East Asians.” ACTA Anthropologica Sinica 32(4): $377-410$.

Wolpoff, Milford H., Alan G. Thorne, and Xinzhi Wu. 1984. "Modern Homo Sapiens Origins: A General Theory of Hominid Evolution Involving the Fossil Evidence from East Asia." In The Origins of Modern Humans: A World Survey of the Fossil Evidence, eds. Fred H. Smith and Frank Spenser, 411-83. New York: Liss. 
WU XINZHI 吴新智. 2000. “Beijing yuanren haishi women de zuxian ma?” 北京猿人还是我们 的祖先吗 [Is Peking Man still our ancestor?]. Guangming daily 光明日报, October 30. . 2006. "Xaindai ren qiyuan de duodiqu jinhua xueshuo zai Zhongguo de shizheng" 现代人起源的多地区进化学说在中国的实证 [Evidence of multiregional human evolution hypothesis from China]. Quaternary Sciences 26(5):702-9.

—. 2008. “Renlei qiyuan de duo diqu Jinhua lun" 人类起源的多地区进化论 [The multiregional hypothesis of human origin]. ScienceNet, March 7. http://blog.sciencenet.cn/ blog-39662-17354.html (accessed May 14, 2017).

XI JingPING 习近平. 2014. “Zai jinian kangzhan baofa 77 zhounian dahui shang de jianghua” 在纪念抗战爆发 77周年纪念大会上的讲话 [Speech at the ceremony in commemoration of 77th anniversary of the breaking of the war against Japanese invasion]. People.cn, July 7. http://politics.people.com.cn/n/2014/0707/c1024-25247770.html (accessed May 28, 2015).

XINHUA SHE 新华社 [XINHUa News Agency]. 2009. "Yibai shou aiguo gequ mindan gongbu" 一百首爱国歌曲名单公布 [List of one hundred patriotic songs]. http://news.xinhuanet. com/politics/2009-05/25/content_11434058.html (accessed April 15, 2015).

Xu Pingfang. 2005. “Introduction Part II.” In The Formation of Chinese Civilization: An Archaeological Perspective, eds. Chang Kwang-chih and Xu Pingfang, 7-9. New Haven, Conn.: Yale University Press.

YANG XUEMEI 杨雪梅. 2015. “Beijing yuanren yonghuo youle xinzheng” 北京猿人用火有了新证 [New evidence for Peking Man's use of fire]. People's Daily, April 2. http://culture. people.com.cn/n/2015/0402/c87423-26787621.html (accessed September 8, 2015).

YAO ZhenGWU 姚振武. 2010. "Renlei yuyan de qiyuan yu gudai hanyu de yuyanxue yiyi" 人类语言的起源与古代汉语的语言学意义 [The origin of human languages and the linguistic significance of ancient Chinese language]. Zhongguo yuwen 中国语文 $114(1): 6-8$.

YE Zong YUAN 叶宗元. 2012. Chuzhong lishi zhishi jijin 初中历史知识集锦 [Junior high school history exercise book]. Nanjing: Nanjing University Publisher.

Zhang LAN TAO 张蹈岗. 2013. "Yichuanxuejie de dianjiren tanjiazhen: Yizhi wanyanshu tuidong baohu Zhongguo renlei jiyin” 遗传学界的鿖基人谈家桢:一纸万言书推动保护中 国人类基因 [Tan Jiazhen, the founder of China’s genetics: A letter of 10,000 words for protection of Chinese human genes]. Shanghai Committee of China Democratic League. http://www.minmengsh.gov.cn/shmm/n51/n53/ulai2531.html (accessed December 20, 2015).

ZhongGuo GongChandang XINWEN 中国共产党新闻 [News of The Communist Party of ChInA]. 1997. “Diyipi baige aiguo zhuyi jiaoyu shifan jidi mingdan” 第一批百个爱国 主义教育示范基地名单 [List of the first one hundred bases for patriotic education]. http://cpc.people.com.cn/GB/33843/2598278.html (accessed May 29, 2014).

Zhonghua Renmin Gongheguo Zhongyang Renmin Zhengfu 中华人民共和国中央人民政府 [The Central People’s Government of the People’s Republic of China]. 2008. “Aoyun shenghuo jixu zai Beijing chuandi” 奥运圣火继续在北京传递 [The Olympic sacred fire continues its relay in Beijing]. August 8. http://www.gov.cn/jrzg/ 2008-08/08/content_1067381.htm (accessed September 8, 2015). 